\title{
REAKTUALISASI KONSEP INTEGRASI ILMU IBNU KHALDUN DALAM PENDIDIKAN ISLAM MODERN
}

Oleh

Nashrullah Muhammad Atha

Dosen Sekolah Tinggi Ilmu Al Qur`an

E-Mail: azzanki04\&gmail.com

\begin{abstract}
Abstrak
الموضوع من البحث في هذا المقال هو كتاب المقدمة لابن خلدون مع التركيز حول تصور إندماج العلم. وهذا البحث لم يتوقف عن تحليل نظرية إندماج العلم عند ابن خلدون, إستفادة لذذه النظرية طرح البحث تطبيقها في هذا العصر بدلا من النظرية الثنائية التى فد تسيطر النظام التعليم الاسلامى. هذا البحث من ضمن البحث المكتى بدراسة كتاب المقدمة جاعلا إياه مصدرا اساسيا وكتبه الاخرى المتعلقة به مصدرا ثانويا. ومن خلال البحث المكتبى علم بأن ابن خلدون عالم متكامل يندمج بين العلوم النقلية والعلوم العقلية. وأما المهنج في هذا البحث فهو منهج وصفى تحليلى بعرض نظرية اندماج العلم عند ابن خلدون ثم تحليلها ليرى مدى مطابقتها بمنهج التعليم الاسلامى في هذا العصر. وأما الهدف من هذا البحث فهو من البحث الوصفى الشرحى بتقديم عرض بناء نظرية ابن خلدون ثم تبيين حججه على
\end{abstract}


Nashrullah Muhammad Atha: Reaktualisasi Konsep Integrasi Ilmu Ibnu Khaldun dalam Pendidikan Islam Modern

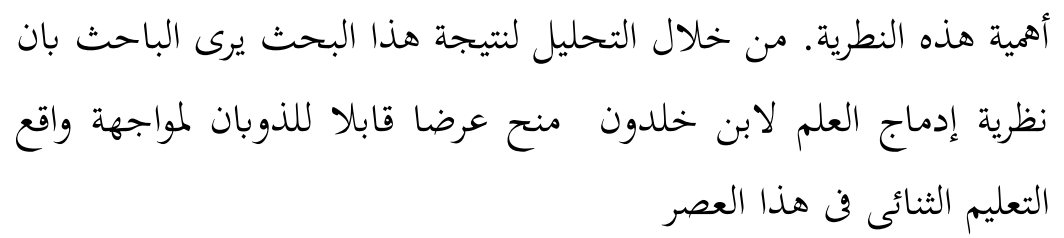

Kata Kunci: Ibnu Khaldûn, integrasi, aqliyah, naqliyah

\section{A. Pendahuluan}

Kualitas peradaban suatu bangsa akan sangat ditentukan oleh grand desingn bangsa tersebut dalam merekaya pendidikan ${ }^{1}$ atau dengan redaksi yang berbeda pendidikan merupakan salah satu instrumen primer eksistensi kebudayaan umat manusia ${ }^{2}$. Bangsa yang berhasil menjadikan pendidikan sebagai setting prioritas maka lahirnya generasi-generasi visioner yang mampu memimpin episode peradaban berikutnya adalah sebuh keniscayaan. Islam sebagai agama wahyu telah berhasil mendesain satu konsep pendidikan berbasis iman dengan nilai-nilai transenden melalui wahyu pertama (the first revelation) ${ }^{3}$

1 M.Natsir sebagai tokoh pendidikan Indonesia sangat menyadari urgensi pendidikan bagi suatu bangsa, dalam pidatonya pada Rapat Persatuan Islam di Bogor pada tanggal 17 Juni 1934 M. Natsir menyampaikan pidatonya, "Maju atau mundurnya salah satu kaum bergantung sebagian besar kepada pelajaran dan pendidikan yang berlaku dalam kalangan mereka" Lihat Thohir Luth, M. Natsir: Dakwah dan Pemikirannya, (Jakarta, Gema Insani, 1999) cet ke. 1, h. 57

${ }^{2}$ Life is education and education is life (Rupert C. Lodge : 1974) Pendidikan tidak akan punya arti bila manusia tidak ada didalamnya. Hal ini disebabkan karena manusia merupakan subjek dan objek pendidikan. Artinya manusia tidak akan bisa berkembang dan mengembangkan kebudayaannya secara sempurna bila tidak ada pendidikan. Untuk itu, tidak berlebihan jika dikatakan eksistensi pendidikan merupakan salah satu syarat yang mendasar bagi meneruskan dan mengekalkan kebudayaan manusia. Lihat Samsul Nizar, Sejarah Pendidikan Islam: Menelusuri Jejak Sejarah Pendidikan Era Rasulullah sampai Indonesia, Kata Pengantar Editor, Quo Vadis Pendidikan Islam Di Indonesia; Menulusuri Sejarah Menuju Paradigma Pendidikan Berkualitas, (Jakarta, Kencana Prenada Media, 2009) cet ke. 3, h. v

314 abad yang lalu, bertempat disebuh goa yang sepi, seorang manusia berkontemplasi untuk kemudian dilantik menjadi seorang Rasul dengan membawa misi peradaban besar yang dimulai dengan pesan wahyu pertama yang berbunyi "Bacalah dengan menyebut nama tuhanmu yang menciptakan" Sebuah pesan fenomenal yang mampu mengintegritaskan setiap eksyen dalam proses pencarian ilmu pengetahuan yang dimulai dari membaca. Pesan ayat ini memberikan satu sinyal kuat kepada setiap umat

Al Qalam: Jurnal Ilmiah Keagamaan dan Kemasyarakatan

Vol. 13, No. 1, Januari-Juni 2019 
Nashrullah Muhammad Atha: Reaktualisasi Konsep Integrasi Ilmu Ibnu Khaldun dalam Pendidikan Islam Modern

dalam melahirikan satu peradaban besar yang telah berhasil menjamu dunia dengan ilmu pengetahuan ${ }^{4}$ selama berabad-abad lamanya.

Kemunculan peradaban Islam dipentas dunia telah berhasil merubah tatanan dunia dengan formulasi peradaban tauhid. Kemajuan materi selama berabad-abad lamanya tidak menyebabkan termarjinalnya sensitivitas spiritual. Pencapaian ilmu pengetahuan bukannya menyebabkan para ilmuan semakin jauh dari Tuhan dan agama. Akan tetapi, pencapaian ilmu pengetahuan yang telah dihasilkan semakin mendekatkan diri mereka terhadap Tuhan dan agama. Fuad Bâsyâ dalam proloknya, "Nadzariyat al-Hadhârah Fî al-Islâm” menuliskan, "Infrastruktur terkuat dalam teori peradaban Islam adalah, tidak adanya pemisahan antara agama dan realitas kehidupan"5. Bagi Fuad Bâsyâ, agama adalah generator pertama dan terkuat dalam merekustruksi suatu peradaban.

Diskripsi integrasi ilmu pengetahuan dalam Islam bukan sebatas teori imajinatif. Realitas sejarah merupakan bukti lahirnya para ulama yang ilmuwan

bahwa setiap disiplin ilmu pengetahuan harus terkoneksikan dengan Allah sebagai Dzat Pencipta manusia sehingga antara ilmu dan iman menjadi satu kesatuan yang tidak bisa dipisahkan. Dalam bahasa Yusuf Qaradhawi dalam kitabnya Al-Hayâtu Ar-Rabbâniyyah

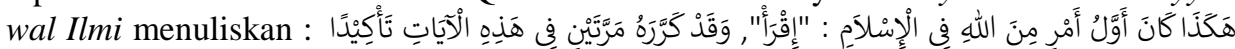

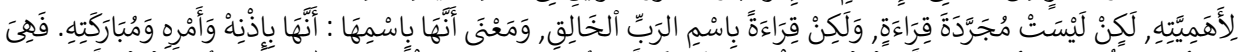

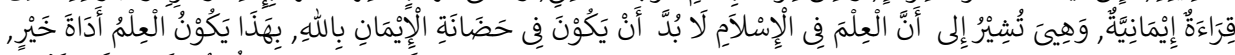

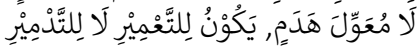

${ }^{4}$ Seorang Filosof Inggris, Thomas Karel menuturkan, sebagaimana yang dikutip oleh Muhammad `Athiyyah al-Abrâsiy dalam bukunya, "Azhamatul Islam”

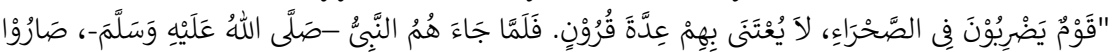

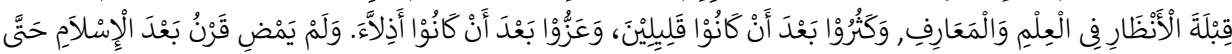

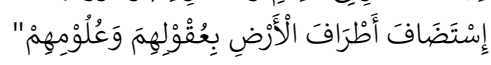

“Komunitas yang dulunya menjadi penghuni sahara yang terisolir beberapa abad lamanya. Ketika seorang Nabi telah diutus Allah, maka jadilah mereka kiblat ilmu \& pengetahuan. Sebelumnya mereka adalah minoritas, akan tetapi mereka telah menjadi mayoritas. Mereka telah menjadi orang-orang mulia, sedangkan dulunya mereka adalah orangorang yang hina. Belum sampai beberapa abad, Islam telah menjamu sisi bumi dengan ilmu \& pengetahuan"

Muhammad Athiyyah al-Abrâs, 'Azhamatul Islam, (Mesir, Maktabah al-Usrah, t.2002) h. 188

5 Al-Majlis al-`Ala li Syưûn al-Islâmiyyah, "Mausû̀ah al-Hadhârah alIslamiyyah",(Mesir, 1426 H/2005, h. 16

Al Qalam: Jurnal Ilmiah Keagamaan dan Kemasyarakatan

Vol. 13, No. 1, Januari-Juni 2019 
Nashrullah Muhammad Atha: Reaktualisasi Konsep Integrasi Ilmu Ibnu Khaldun dalam Pendidikan Islam Modern

dan ilmuwan yang ulama. Sejarah telah memvisualisasikan kepada kita lahirnya ilmuan yang menjadikan nilai ketauhidan, ubudiyah dan moralitas pada setiap karyanya. Para saintis muslim, sebut saja seperti Al Kharijmi ( Algorism 780850) ${ }^{6}$, Ibnu Rusyd (Averroes 502-596) ${ }^{7}$, Ar-Râzi (Rhazes 865-925) ${ }^{8}$, Ibnu Haitsam (Alhazen 354- ) $^{9}$ dan saintis-saintis muslim lainnya. mereka adalah

6 Al-Khawarizmi terkenal dengan teori Algoritmanya. Selain itu, ia juga menciptakan teori matematika lain. Misalnya, aljabar, yang disebut aritmetika (ilmu hitung) oleh para ilmuwan Barat. Dalam buku ini Al Khawarizmi memperkenalkan angka Arab (system per-sepuluh) yang aslinya adalah angka India. Pada tahun 1857 di perpustakaan Universitas Cambridge ditemukan teks atau naskah aritmatika karya seorang Muslim dalam terjemahan bahasa Latin bertajuk 'Algoritimi de Numero Indorum'.Naskah ini diawali dengan kalimat, “Telah berkata Algoritimi. Marilah kita haturkan pujian kepada Tuhan, Pemimpin dan Pelindung kita. Fahmi Amhar, TSQ Stories "Kisah-Kisah Penelitian dan Pengembangan Sains dan Teknologi di Masa Peradaban Islam, (Jakarta, Al-Azhar Press, 2010) cet ke. 1, h. 41

${ }^{7}$ Ibnu Rusyd dilahirkan di Cordova, Selain sebagai seorang ahli filsafat, ia juga dikenal pakar di bidang kedokteran, sastra, logika, ilmu pasti, dan ilmu agama dengan objek studi ilmu tafsir Al-Quran dan hadits, ilmu hukum dan fikih (Bagi kalalngan pesantren dan perguruan tinggi tidak akan pernah melupakan karya Ibnu Rusyi dalam studi fiqih komperatif yang berjudul "Bidâyatul Mujtahid" Sebuah karya yang mendiskripsi fiqih perbedaan pendapat di antara pala ulama madzhab). Ibnu Rusyd telah menghasilkan lebih dari dua puluh buku kedokteran. Salah satunya adalah al-Kulliyyat fi al-Thibb, yang kemudian diterjemahkan dalam bahasa Latin.

${ }^{8}$ Ar Razi adalah seorang dokter muslim yang pertama medeskripsikan dengan jelas cacar dan campak serta menduga akan merangsang timbulnya kekebalan yang disejajarkan dengan Hipokrates. Dalam orisinalitas deskripsi suatu penyakit, Razi dikatakan telah menulis lebih dari dua ratus kitab dengan subyek menyangkut dari kedokteran sampai kimia, theologi dan astronomi. Kebanyakan masa hidupnya dihabiskan untuk mengkaji ilmu-ilmu seperti kimia, filsafat, logika, matematika dan fisika.

${ }^{9}$ Ibnu Haitham dilahirkan di Basrah pada tahun 354H. Dunia mengenalnya sebagai Bapak Optik. Dengan belajar secara otodidak ia mempelajari hingga menguasai beragam disiplin ilmu seperti ilmu falak, matematika, geometri, pengobatan, fisika, dan filsafat. Secara serius dia mengkaji dan mempelajari seluk-beluk ilmu optik. Beragam teori tentang ilmu optik telah dilahirkan dan dicetuskannya. Tak banyak orang yang tahu bahwa orang pertama yang menjelaskan soal mekanisme penglihatan pada manusiayang menjadi dasar teori optik modern — adalah ilmuwan Muslim asal Irak. Pada 1572, karya Ibnu Haitham ini diterjemahkan ke dalam bahasa Latin dengan judul Opticae Thesaurus.

Al Qalam: Jurnal Ilmiah Keagamaan dan Kemasyarakatan

Vol. 13, No. 1, Januari-Juni 2019 
Nashrullah Muhammad Atha: Reaktualisasi Konsep Integrasi Ilmu Ibnu Khaldun dalam Pendidikan Islam Modern

sampel ulama ilmuwan dan ilmuwan ulama yang telah berhasil menampilkan maha karya yang terus dikenang dalam sejarah sebagai bukti bahwa tidak ada dikotomi antara ilmu pengetahuan dan agama, keduanya selalu harmonis melahirkan peradaban rabbaniyah

Secara faktul dengan memperhatikan pendidikan kekinian secara umum dan pendidikan Islam secara khusus tervisualisasikan realitas pendidikan dikotomik $^{10}$ dengan indikator terjadinya pemisahan antara kecerdasan intelektual dan kesalehan moralitas. Dengan memposisikan materi-materi umum sebagai prioritas kecerdasan kognitif menjadi indicator keberhasilan pendidikan telah menjadikan nilai-nilai agama termarjinalkan dalam setiap proses pencapaian pendidikan. Keterhubungan organik antara ilmu dan iman bukan menjadi satu indikator keberhasilan pendidikan. Realitas pendidikan kekiniaan tanpa disadari telah memarjinalkan nilai-nilai transendin yang tergantikan dengan pendekatan rasional empiris saintifik.

Sementara itu, realitas pendidikan Islam yang berikhtiyar secara konseptual mengintegrasi antara ilmu wahyu dan ilmu rasional masih belum mampu melahirkan para ulama yang ilmuan dan ilmuan yang ulama. Sebagain besar pondok pesantren masih menjadikan materi-materi umur sebagai pelengkap administratif agar mendapatkan legalitas akademik pada jenjang berikutnya tanpa mampu mensinergikan dengan materi-materi keagamaan.

${ }^{10}$ Dikotomi ilmu pengetahuan di Indonesia adalah ciptaan dan rekayasa Penjajah Belanda yang berpandangan sekularistik, yaitu pandangan yang memisahkan antara urusan agama dengan urusan keduniaan, seperti ilmu pengetahuan, politik dan lainnya. Belanda telah menerapkan politik yang sangat diskrimintatif terhadap rakyat jajahannya terutama Islam. Pada masa itu pendidikan Islam sangat dibatasi bahkan dicurigai, karena mereka menganggap bahwa pendidikan Islam tidak diperlukan untuk kepentingan pembangunan ekonomi, politik dan sebagainya. Bahkan pendidikan Islam dianggap membahayakan karena di dalam ajaran Islam yang diajarkan dalam pendidikan Islam terdapat konsep jihad atau perang melawan pemimpin yang zalim, dan ajaran yang tidak boleh membolehkan umat Islam memiliki pemimpinnya yang tidak seagama dengannya. Pandangan dikotomis ilmu pengetahuan yang diwariskan oleh Belanda hingga kini masih cukup kuat pengaruhnya. Lihat Abuddin Nata, et al.eds. Integrasi Ilmu Agama dan Umum (Jakarta:Grafndo Persada, 2005), h 54

Al Qalam: Jurnal Ilmiah Keagamaan dan Kemasyarakatan

Vol. 13, No. 1, Januari-Juni 2019 
Nashrullah Muhammad Atha: Reaktualisasi Konsep Integrasi Ilmu Ibnu Khaldun dalam Pendidikan Islam Modern

Sedangkan madrasah dengan ikhtiyarnya mensinergikan materi agama dan umum dalam proses dihadapkan dengan dualisme materi pembelajaran sekaligus penambahan materi ajar yang secara signifikan akan mempengaruhi kuantitas dan kualitas materi ajar madrasah. Realitas dikotomi ilmu dan semakin melemahnya peran materi madrasah dapat dilihat dari kurikulum 1994 dengan diwajibkannya madrasah menyelenggrakan $100 \%$ materi umum. Dan ini berimplikasi pada out put yang dihasilkan madrasah yang tidak memiliki kejelasan ${ }^{11}$ dalam segala asfek, baik kualitas, peran maupun orientasi dan tujuan jangka panjang dalam menghadapi globalisasi. ${ }^{12}$

Tulisan ini akan mendiskripsikan konsep pendidikan integratif yang merupakan hasil dari analisis realitas sosial diawal XV M yang kemudian dielaborasi dalam konteks pendidikan. Diharapkan dari kajian ini menjadi satu tawaran alternatif konsep integrasi ilmu pengetahuan yang masih menjadi problematika dalam diskursus pendidikan kekinian sehingga pendidikan merupakan satu konstelasi transformation of knowledge yang tersinergikan dengan transformation of value. Dari hasil kajian peneliti, teori ini bukan sebatas teori lama akan tetapi merupakan teori aplikatif yang melintasi zamannya dan geografisya.

Salah tokoh intelektual pendidikan dengan magnum opusnya Muqqadimah telah mendesain konsep pendidikan integratif. Sebagai sebagai

${ }^{11}$ Menurut Mujamil Qamar, Madrasah masih sering dipandang sebelah mata sebagai lembaga pendidikan kelas kedua (ekonomi). Madrasah diangkap sebagai lembaga pendidikan kepalang tanggung, sehingga muncul opini yang berkembang dimasyarakat bahwa alumni madrasah tidak bisa melanjutkan ke sekolah umum atau negeri pada jenjang di atasnya. Alumni madrasah diopinikan hanya menjadi modin. Alumni madrasah juga diopinikan tidak diterima di dunia kerja, dan sebagai stigma negative lainnya yang ditempelkan pada madrasah meskipun bertentangan dengan ketentuan perundangundangan. Lihat Mujamil Qamar, Dimensi Manajemen Pendidikan Islam, (Jakarta, Emir, 2015), h.

${ }^{12}$ Muslih Usa, et.al, Pengantar, dalam Pendidikan Islam di Indonesia: Antara Cita dan Fakta (Yogyakarta: PT Tiara Wacana Ilmu, 1997), h.7 
Nashrullah Muhammad Atha: Reaktualisasi Konsep Integrasi Ilmu Ibnu Khaldun dalam Pendidikan Islam Modern

seorang sosiolog arab muslim integratif ${ }^{13}$ Ibnu Khaldûn telah berhasil mendesain konsep pendidikan integratif yang terkoneksikan dengan nilai-nilai keimanan.

Dengan Muqqadimahnya, Ibnu Khaldûn mendiskripsikan sepertiga diantaranya mengenai pendidikan. Fokus kajian mengenai pendidikan Ibnu Khaldûn diskripsikan pada pasal keenam dari kitab pertama dengan objek kajian diantaranya mengenai karakteristik ilmu, klasifikasi ilmu pengetahuan, konsep pengajaran, motede pengajaran dan tema-tema pendidikan lainnya.

Kajian Ibnu Khaldûn mengenai pendidikan bukan sebatas kajian teoritas akan tetapi merupakan satu kajian empiris terhadap realitas sosial yang terjadi dizamannya. Dan ketika studi Ibnu Khaldûn mengenai pendidikan direkonstruski kembali maka bukan sebatas penelitan individual life history. Kajian terhadap pemikiran pendidikan Ibnu Khaldûn merupakan kajian kontekstualisasi adaptif realistis yang masih memiliki relevansi untuk menjawab tantangan problematik pendidikan kekinian.

Tulisan ini merupakan ikhtiyar dalam memberikan satu ruang terhadap konsepsi pendidikan Islam integratif. Dari ikhktiyar sederhana ini diharapakan menjadi satu visual bahwa konsep-konsep pendidikan klasik bukan sebatas konsep lokal historis. Konsep-konsep pendidikan klasik Islam merupakan konsep pendidikan universal yang seharusnya menjadi perhatian para peneliti pendidikan Islam dalam melakuan eksplorasi teks-teks klasik untuk selanjutnya dilakukan analisis kontekstual. Akhir dari tulisan berikhtiyar menjadikan konsep pendidikan Islam sebagai sprit implementatif dalam memberikan solusi-solusi realistis terhadap problematikan pendidikan modern dewasa ini.

13 Mohamam Pribadi dalam jurnalnya yang berjudul, Tahapan Pemikiran Masyarakat Dalam Pandangan Ibnu Khaldun berpendapat bahwa salah satu kualifikasi standar akademik yang cukup sulit dipenuhi hampir disemua fakultus sosiologi adalah ditemukan lulusun yang bergelar al "hâfidz" sekaligus sebagai sosiolog. Lihat, Sosiologi Reflektif, Volume 11. No 2 April 2017, h. 33

Al Qalam: Jurnal Ilmiah Keagamaan dan Kemasyarakatan

Vol. 13, No. 1, Januari-Juni 2019 
Nashrullah Muhammad Atha: Reaktualisasi Konsep Integrasi Ilmu Ibnu Khaldun dalam Pendidikan Islam Modern

\section{B. Metode Penelitian}

Metode dapat diartikan sebagai suatu prosedur atau cara untuk mengetahui sesuatu yang mempunyai langkah-langkah sistematis. ${ }^{14}$ Jenis penelitan pada tulisan ini adalah studi kepustakaan (library research) Menurut Sugiyono, studi kepustukaan berkaitan dengan kajian teoritis dan referensi lain yang berkaitan dengan nilai, budaya, norma yang berkembang pada situasi sosial yang diteliti. Selain itu studi kepustakaan sangat penting dalam melakukan penelitian, hal ini dikarenakan penelitan tidak lepas dari literatur-literatur ilmiah. $^{15}$

Dilihat dari sifat tujuannya, penelitian ini termasuk penelitan deskriptif eksplantif, yaitu dengan mendiskripsikan terlebih dahulu bagaimana kontruski teori Ibnu Khaldûn mengenai integrasi ilmu lalu menjelaskan argumentasi Ibnu Khaldûn mengenai teori tersebut.

Secara metode, penelitian ini menggunakan metode deskriptif yaitu metode yang tidak menguji hipotesis atau tidak menggunakan hipotesis, melaikan hanya mendiskripsikan informasi apa adanya sesuai dengan variabel-variabel yang diteliti. ${ }^{16}$ Diskripsi kontruksi teori integrasi ilmu Ibnu Khaldûn dianalisis dengan menggunakan tekhnik analisis isi (content analysis) dengan melakukan analisis terhadap isi dari satu temuan ilmiah ${ }^{17}$ sehingga akan ditemukan relevansi teori integrasi ilmu Ibnu Khaldûn dalam memberikan solusi adabtif terhadap pendidikan Islam kekinian dalam konteks integrasi ilmu

Dari asfek pendekatan, penelitian ini menggunakan pendekatan tematis (tipical appoarch). Pendekatan ini terfokus pada studi analitis untuk

\footnotetext{
${ }^{14}$ I Made Wirantha, Metode Penelitian Sosial Ekonomi, (Yogyakarta, Andi, 2006), 69

${ }^{15}$ Sugiyono, Metode Penelitian Kuantitatif dan $R \& D$, (Bandung, Alfabete, 2012) h. 38

${ }^{16}$ Mardalis, Metode Penelitian: Sesuatu Pendekatan Proposal, (Jakarta, Bumi Aksara, 1995), 26

17 Noeng Muhajir, Metode Penelitian Kualitatif, (Bandung, PT Remaja Rosdakarya, 1990), h. 48
} 
Nashrullah Muhammad Atha: Reaktualisasi Konsep Integrasi Ilmu Ibnu Khaldun dalam Pendidikan Islam Modern

membedakan konsep pemikiran seorang tokoh dengan tokoh lain dalam objek keilmuan tertentu. ${ }^{18}$ Dalam konteks penelitian ini, konsep pemikiran Ibnu Khaldûn mengenai integrasi ilmu diharapkan nanti akan menjadi bahan kajian komperasi dengan konsep integrasi ilmu lainnya.

Data-data yang diteliti pada penelitian terdiri dari data primer dan sekunder. Muqaddimah dan At Ta` rîf bi Ibn Khlaldûn wa Rihalâtuhu Gharban wa Syarqan sebagai data primer yang merupakan karya Ibnu Khaldûn. Sedangkan data sekunder diambil dari kitab-kitab, buku-buku dan beberapa artiker yang mengkaji pemikiran Ibnu Khaldûn dengan fokus studi pada pemikiran pendidikan yang semuanya merupakan hasil dari interpretasi dari data primer.

\section{Sketsa Intelektualisasi Ibnu Khaldûnn}

Ibn Khaldūn dalam autobiografinya ${ }^{19}$ mendiskrisikan dirinya bernama adalah 'Abd al-Rahmān ibn Muhammad ibn Muhammad ibn Muhammad ibn alHasan ibn Muhammad ibn Jābir ibn Muhammad ibn Ibrāhīm ibn 'Abd al-Rahmān ibn Khaldūn. Ibnu Khaldûn juga dikenal bernama Abū Zaid Walīy al-Dīn ibn Khaldūn yang merupakan gelar yang diberikan kepadanya setelah diangkat menjadi hakim di Mesir. ${ }^{20}$

Khaldūn adalah generasi yang berimigrasi ke Sevilla, Andalusia ${ }^{21}$ bersama pasukan Yamaniyah yang ikut serta dalam penaklukan Andalusia dibawah pimpinan Thâriq bin Ziyâd pada tahun 96 H (711 M). ${ }^{22}$ Nasab Ibnu Khaldun sampai kepada Wa`il Ibnu Hujr, seorang sahabat Nabi yang pernah

${ }^{18}$ Burhan Bungi, Analisis Data Penelitan Kualitatif, Pemahaman Filsafat dan Metodologis ke Arah Penguasaan Model Aplikasi, (Jakarta, Raja Grafindo Persada, 2003), h. 115

${ }^{19}$ Muhammad Fārūq al-Nabhān, al-Fikr al-Khaldūnī min Khilāl al-Muqaddimah (Beirut-Lebanon: Mu'assasah al-Risālah, cet. I, 1417 H/1998 M), h. 35.

20 'Al̄̄ 'Abd al-Wāhid Wāfì,'Abd al-Rahmān ibn Khaldūn: Hayātuhu wa Ātsāruhu wa Mazhāhir 'Abqariyyatihi (Mesir: Maktabah Misr, t.t ), h. 12.

21 Muhammad Fārūq al-Nabhān, al-Fikr al-Khaldūn̄̄ min Khilāl alMuqaddimah, h. 38

${ }^{22}$ Ismail Sirâjuddîn, Ibnu Khaldûn Injâzun Fikriyyun Mutajaddidun, (Mesir, Maktabah Iskandariyah, 2008), h.11

Al Qalam: Jurnal Ilmiah Keagamaan dan Kemasyarakatan

Vol. 13, No. 1, Januari-Juni 2019 
Nashrullah Muhammad Atha: Reaktualisasi Konsep Integrasi Ilmu Ibnu Khaldun dalam Pendidikan Islam Modern

mendapatkan doa Rasulullah agar semua keterunannya selalu dalam berkah Allah sampai hari kiamat. ${ }^{23}$

Sketsa perjalanan ilmiah Ibnu Khaldûn telah dituliskan oleh Dr. Muhamamd Fârûq An Nabhân kepada empat fase:

\section{Fase Kelahiran dan Pertumbuhan}

Fase ini berlangsung selama 19 tahun, dimulai semanjak lahirnya Ibnu Khaldûn pada tahun 732 H sampai 751 H. Semua fase ini Ibnu Khaldûn habiskan ditempat kelahirnya Tunisia dengan mengambil sanad keilmuan bersama para ulama Tunisia yang memiliki kedekatan tipologi emosional pemikiran dengan ayah Ibnu Khaldûn. Ayah Ibnu Khaldû dan para ulama yang menjadi guru Ibnu Khaldûn adalah mereka yang mensterisasi komunitasnya dari dunia politik

Dinamika masyarakat Tunisia yang relatif stabil telah memberikan ruang bagi Ibnu Khaldûn muda pada fase ini memformulasikan kepribadian, wawasan dan keilmuan. Dinamika ini sangat berbeda ketika keluarga Ibnu Khaldûn berdomisili di Sevilla Andalusia yang lebih komplek. Seandainya Ibnu Khaldûn tetap tinggal di Tunisia yang lebih realatif kondusif dengan tetap mengikuti metode ilmiyah ayahnya, tentunya Ibnu Khaldûn tidak memiliki ruang dalam menulis kajian filsafat sejarah, peradaban dan politik.

Diera kekuasan Sultan Al Murîni Abû Al Hasan pada tahun 784, Ibnu Khaldûn sangat mengagumi sultan dan termasuk pula para ulama yang telah dipilih oleh sultan dari Magribi dan Tunisia. Pada masa ini terjadi peristiwa Al Qairuwân dimana rakyat Tunisia memprotes kebijakan sultan dan

${ }^{23}$ Dalam kitab Tharhu Tatsrib Imam Nâshiruddîn Abi Khair Abdullah bin Umar وائل بن حجر بن ربيعة بن وائل بن يعمر الحضري يكنى أبا هنيدة (

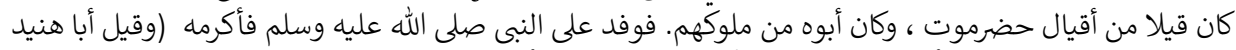

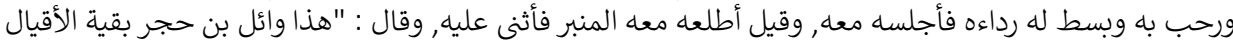

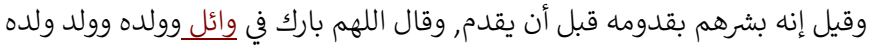

Imam Nẩshiruddîn Abi Khair Abdullah bin Umar,Tharhu Tatsrîb, (Mesir, Dâr Ihyâ Turâts Al Arabiyyi, t.t), h. 121

Al Qalam: Jurnal Ilmiah Keagamaan dan Kemasyarakatan Vol. 13, No. 1, Januari-Juni 2019 
Nashrullah Muhammad Atha: Reaktualisasi Konsep Integrasi Ilmu Ibnu Khaldun dalam Pendidikan Islam Modern

mengepung sultan. Akan tetapi pada akhirnya Sultan berhasil lulus dan kembali berkuasa.

\section{Fase Kedua: Era Politik Praktis}

Fase ini berlangsung selama 25 tahun, dimulai pada tahun $751 \mathrm{H}$ ketika Ibnu Khladû dilantik sebagai sekretaris Perdana Menteri otoriter yang bernama Ibnu Tâfrâkin sampai tahun $776 \mathrm{H}$ disaat kepulangan kedua Ibnu Khaldûn ke Andalusia dan pada ketika Ibnu Khaldûn berkontemplasi seorang diri di benteng Ibnu Salamâh. Pada fase produktif yang cukup stabil inilah terjadi pengalaman yang cukup mendalam disertai keinganan dengan adanya kesempatan yang ia lihat. Fase ini Ibnu Khaldûn hidup dengan dualism kejiwaan, jiwa yang mengalami goncangan sekaligus kelelahan dan kesedihan. Akan tetapi disisi lain, pada beberapa waktu tertentu, kehidupan Ibnu Khaldûn relatif menyenangkan. Disaat dalam kesendirian yang bekelanjutan, Ibnu Khaldûn juga bermimpi kemulian akan tetapi mimpi tersebut lenyap dengan sendirinya yang pada akhirnya meninggalkan rasa sakit dan sedih.

Instabilitas kejiwan semacam ini mungkin saja awal dari fase ini yang mengindikasikan bahwa Ibnu Khaldûn memiliki mimpi-mimpi panjang yang kemudian memulai fase baru berikutnya dengan adanya keinginan lari dari kehidupan politik praktis untuk mencari stabilisasi kejiwaan yang akan memproteksi kemuliannya dan ambisi-ambisinya.

\section{Fase Ketiga : Aktifitas Menulis dan Produktifas Ilmiyah}

Fase ini berlangsung selama 8 tahun, dimulai dari akhir-akhir tahun 776 sampai pada akhir-akhir tahun 748. Pada fase ini Ibnu Khaldûn berkonsentrasi pada aktifitas ilmiyah setelah kejiwaannya merasa sempit dengan aktifitas politik.

Selama 4 tahun dengan kesendiriannya di benteng Ibu Salamâh, Ibnu Khaldûn menjadi seorang zuhud dengan mengisolasi dari manusia berkonsentrasi pada aktifitas menulis. Dari fase inilah lahir karya terpenting dalam kehidupan Ibnu Khaldûn. Sebuah karya yang terlahir dari kondisi 
Nashrullah Muhammad Atha: Reaktualisasi Konsep Integrasi Ilmu Ibnu Khaldun dalam Pendidikan Islam Modern

emosional yang teradaptasikan dengan realitas kehidupan ketika itu telah memberikan corok tersendiri terhadap orisinalitas dan keindahan kreatifitas berfikir yang terbentuk dari beragam teori holistik mengenai negara, fanatisme, kultur dan peradaban.

Di tengah kesendiriannya yang sangat melelahkan setelah empat tahun muncul kerinduan untuk membaca buku-buku dan beragam tulisan yang hanya bisa ditemukan di kota-kota, sebuah kerinduan kepada kehidupan sebelumnya dan keinginan dunia kemarin.

Dari keinginan inilah, Ibnu Khaldûn berinisiatif menulis surat kepada Sultan Abas yang kemudian direspon secara positif oleh Sultan agar kiranya Ibnu Khaldûn menghentikan uzlahnya. Respon ini memunculkan keinginan baru Ibnu Khaldûn untuk duduk di majlis-majlis sultan. Akan tetapi, dorongan penolokan begitu kuat yang mengingatkan Ibnu Khaldûn kepada kesedihan masa lalu yang sangat melelahkan dan memutus asakan. Memory inilah mengembalikan Ibnu Khaldûn ke benteng Abi Salamâh dengan membawa kesedihan dan rasa sakit. Ibnu Khaldûn berkeingian mencari benteng baru yang jauh untuk menghapuskan tulisan sejarah masa lalu dengan membuka lembaran sejarah baru yang lebih bersih dan Mesir menjadi pilihan Ibnu Khaldûn.

\section{Fase Keempat : Fase Mengajar dan Sebagai Qadhi}

Fase ini berlangsung selama 24 tahun, dimulai dari akhir tahun 784 dan berakhir pada akhir tahun 808. Fase ini menjadi fase penyempurna fase sebelumnya. Idealnya fase ini terbagi menjadi dua, fase sebagai politisi praktis dan fase sebagai akademisi. Pada fase pertama inilah Ibnu Khaldûn tenggelam dalam lautan dalam dunia politik praktis begitu lama sehigga ia sendiri tidak mampu untuk menghentikan dirinya kecuali setelah menempuh perjalanan yang begitu panjang melelahkan untuk melanjukan kepada perjalanan baru dengan dunia baru pula. 
Nashrullah Muhammad Atha: Reaktualisasi Konsep Integrasi Ilmu Ibnu Khaldun dalam Pendidikan Islam Modern

\section{Epistemologi Integrasi Ilmu Pengetahuan Ibnu Khaldûl}

Ibnu Khaldûn mendiskripsikan materi integrasi ilmu pada kitabnya $\mathrm{Al}$ Muqaddimah pada pasal keenam dari kitab pertama mengenai beragama ilmu pengetahuan, klasifikasi ilmu, pembelajaran, metode pembelajaran dan tematema lainya mengenai ilmu pengetahuan. ${ }^{24}$

Pada bab keenam ini Ibnu Khaldûn menjelaskan mengenai desain pendidikan Islam dan strategi idealanya. Sebagai insan berfikir, potensi berfikir manusia harus tereksplorasi dalam membangun peradaban. Dalam pandangan Ibnu Khaldûn, ilmu pengetahuan bukan sebatas hafalan, akan tetapi ilmu pengetahuan adalah skil yang harus terus dikembangan dengan kemampuan melakukan eksplorasi diri dalam studi-studi ilmiah. Relasi ilmu pengetahuan dengan kemajuan dan kemunduran peradaban merupakan satu keniscayaan

Membaca pemikiran Ibnu Khaldûl mengenai pendidikan, maka menurut Dr. Abdul Amir Syamsuddîn dalam Mausû'ah At Tarbawiyah wa Ta'lîm Al Islamiyyah Al Fikru At Tarbawiyyu `inda Ibnu Khaldûn wabnu Al Arzâq tidak bisa dilepaskan dari konsep filosfis Ibnu Khaldûl mengenai sejarah dan peradaban dalam membangun peradaban manusia disatu sisi dan konsep pemikiran manusia disisi lain. ${ }^{25}$ Dalam pendangan Ibnu Khaldûn, Ilmu pengetahuan dan pembelajaran merupakan suatu yang natural dalam peradaban umat manusia. ${ }^{26}$

Konsep pemikiran integratif Ibnu Khaldûn bukan sekader kajian teoritis konseptual akan tetapi merupakan kajian apllikatif yang teraktualisasi pada tipoligi pemikiran Ibnu Khaldûn yang selanjutnya tervisualisasi pada pengusaan beragama ilmu pengetahuan integratif pada diri Ibnu Khladûn sendiri.

24 Waliyuddîn Abdurrahman bin Muhammad, Muqaddimah Ibnu Khaldûn,(Damsyik, Dârul Balkhi, 2004), h. 155

${ }^{25}$ Abdul Amir Syamsuddîn, Mausû̀ah At Tarbawiyah wa Ta 'îm Al Islamiyyah Al Fikru At Tarbawiyyu `inda Ibnu Khaldûn wabnu Al Arzâq, (Libanor, dâr Al Iqrâ, 1404/1984 M), h. 61

${ }^{26}$ Waliyuddîn Abdurrahman bin Muhammad, Muqaddimah Ibnu Khaldûn, h. 
Nashrullah Muhammad Atha: Reaktualisasi Konsep Integrasi Ilmu Ibnu Khaldun dalam Pendidikan Islam Modern

\section{Pribadi Integratif}

Autobiografi yang ditulis sendiri oleh Ibnu Khaldûn pada proses pengembaraan ilmu pengetahuan telah memformulasikan Ibnu Khaldûn sebagai pribadi integratif. Fase ini merupakan fase pertumbuhan Ibnu Khaldûn dengan fokus pada studi yang ia habiskan di Tunisia. ${ }^{27}$ Ibnu Khaldûn menusliakan fase ini

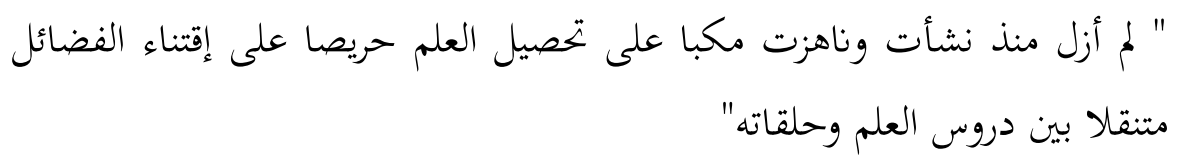

Ibnu Khaldûn memulai pengembaraan intelektualnya dengan fokus pada ilmu-ilmu agama. Pendidikan Al-Qur`an menjadi prioritas utama yang dimulai dengan proses menghafal dan qaidah tajwid kemudian dilanjutkan dengan studi qiraat secara talaqqi bersama para ahli qiraat profesional dimasanya sehingga Ibnu Khaldûn telah menguasai ilmu qirâ’at sab`ah, lebih spesifik lagi qirâ‘at Yàqûb ibnu Ishaq bin Zaid ibn Abdillah (1182014) ${ }^{28}$ Penguasaan materi Al Qur’an tidak berhenti sampai disini saja, Ibnu Khaldûn juga mempelajari ilmu rasam Al Qư’an sesuai matan al Lâmiyyah dan al Râ`iyyah karangan Imam Syâtibiyy $\left(538-590\right.$ H) ${ }^{29}$

Setelah menyelesaikan studi qirâ'at Ibnu Khaldûn melanjutkan dengan studi tafsir, hadits, ushul fiqih dan fiqih madzhab Maliki yang menjadi standar hukum masyarakat Maqribi. Disamping itu pula, Ibnu Khaldûn juga mempelajari ilmu-ilmu instrumental linguistik yang menjadi basis untuk memahami ilmu-ilmu keagamaan seperti ilmu nahwu (sintaksis), Sharaf (morfologis), balaqah dan sastra.

${ }^{27}$ Abdul Amir Syamsuddîn, Mausû`ah At Tarbawiyah wa Ta`lìm Al Islamiyyah Al Fikru At Tarbawiyyu `inda Ibnu Khaldûn wabnu Al Arzâq, h. 13

${ }^{28}$ Abdurrahmân bin Khaldûn, At Ta rîf bi Ibni Khaldûn wa Rihlatihi Garban wa Syarqan, (Lebanon, Dârul Kitâb, 1979), h. 17

${ }^{29}$ Abdurrahmân bin Khaldûn, At Ta`rîf bi Ibni Khaldûn wa Rihlatihi Garban wa Syarqan, h. 18

Al Qalam: Jurnal Ilmiah Keagamaan dan Kemasyarakatan Vol. 13, No. 1, Januari-Juni 2019 
Nashrullah Muhammad Atha: Reaktualisasi Konsep Integrasi Ilmu Ibnu Khaldun dalam Pendidikan Islam Modern

Pribadi integratif seorang Ibnu Khaldûn dapat dengan mudah dilihat dari dua orang guru yang ia sebatkan sebagai 2 tokoh yang banyak mempengaruhi pengembangan intelektualitas Ibnu Khaldûn. Pertama, Abû Muhammad ibn Abdul Muhaimin ibn Abdul Muhaimin Al Hadramî, sebagai ulama yang expert dalam studi nahwu dan imam para muhaddtsîn Maqribi. Dari Abu Muhammad, Ibnu Khaldûn mengambil sanad keilmuan hadits, ${ }^{30}$ musthalahul hadits, sejarah nabi dan ilmu-ilmu lingustik. Kedua, Abû Abduillah ibn Ibrâhîm Al Abilî, guru dengan kajian ilmu-ilmu rasional. Dari sini Ibnu Khaldûn belajar ilmu filsafat, ilmu logika, metafisika, matematika, ilmu alam, ilmu falak dan musik. ${ }^{31}$

Diusianya yang ke 20 tahun Ibnu Khaldûn telah berhasil menyelesaikan materi-materi pembelajaran integratif dan mendapat legitimasi untuk mengajar berupa ijazah tadrîs dari sebagian besar gurunya.

\section{Berfikir Integratif}

Manusia adalah makhluk dengan kemampuan berfikir yang tidak dimiliki oleh binatang. Dengan kemampuan berfikir inilah manusia bisa hidup dan saling berinteraksi. Dengan kemampuan berfikir ini pula manusia mengenal Tuhannya dan memahami pesan-pesan rasul-Nya. ${ }^{32}$

Menurut Ibnu Khaldûn, terciptanya menusia sebagai makhluk berpikir bukan sebatas untuk kepuasan materi maupun sosial. Dengan kemampuan berfikir manusia harus mampu berkontemplasi dengan objekobjek ciptaan Allah sesuai dengan yang dipesankan oleh rasul-Nya. Kemampun berfikir manusia harus bersifat integratif untuk saling bersinergi. Dalam perspektif Ibnu Khaldûn kata afidah dalam surah Al Muluk ayat 23 bermakna kegitan berfikir dan kegiatan berfikir adalah,

${ }^{30}$ Diantara murid Ibnu Khaldûn yang expert dalam ilmu hadits adalah Ibnu Hajar Al `Asqalâni yang sering ber-talaqqi bersama Ibnu Khaldûn dalam beberapa kajian keilmuan dan sejarah. Terjemah Ibnu Khaldun, h. 1082

${ }^{31}$ Abdurrahmân bin Khaldûn, At Ta`rîf bi Ibni Khaldûn wa Rihlatihi Garban wa Syarqan, h.19

${ }^{32}$ Abdurrahman bin Khaldûn, Muqaddimah Ibnu Khaldûn, h.155

Al Qalam: Jurnal Ilmiah Keagamaan dan Kemasyarakatan

Vol. 13, No. 1, Januari-Juni 2019 
Nashrullah Muhammad Atha: Reaktualisasi Konsep Integrasi Ilmu Ibnu Khaldun dalam Pendidikan Islam Modern

sebuah persepsi terhadap suatu yang abstrak dan adanya gerak pikiran baik secara acak dan terstruktur.

Ada tiga tingkatan berfikir manusia yang kesemuanya harus terintegrasi, dimulai dari al `aqlu at-tamyîzî̀ kemudian al `aqlu at tarjibiy dan diakhir dengan al 'aqlu an nazhariy. ${ }^{33}$

Pertama al ‘aqu at tamyizil akal pembeda adalah kemampuan berfikir terhadap satu konsekuensi yang belum terjadi, baik secara natural maupun yang telah terformulasi secara struktural yang memang diinginkan akan terjadinya sesuai dengan kemampuan. Konsep berfikir semacam lebih dalam kerangka persepsi. Fungsi akal hanya sebatas untuk mendapatkan manfaat hidup sekaligus agar terhindar dari kemudharatan hidup.

Kedua al ‘aqlu at tarjibiy/ akal ekspremental adalah kemampuan berfikir yang menghasilkan berbagai konsep pemikiran rasional dan etika interaksi yang dihasilkan melalui ekspreman secara gradual. Konsep berfikir semacam sudah masuk pada kemampuan berfikir apersepsi

Ketiga al 'aqlu an-nazhari/berfikir teoritis adalah kemampuan berfikir yang menghasilkan kenyakinan atau masih bersifat asumsi terhadap satu objek yang abstrak tanpa ada tindakan kongkret. Al ‘aqlu an nazhari terkonstrusi dari persepsi (tashawwur) dan apersepsi (thasdîq) yang terformulasi secara khusus dengan syarat spesifik sehingga memunculkan pengetahuan-pengetahuan baru dari jenis yang sama, baik dalam hal persepsi atau apersepsi. Dari formulasi ini terkonstruski kembali dengan yang lainnya sehingga melahirkan pengetahuanpengetahuan lainnya. Tujuan akhir dari al ‘aqu an nazhari adalah tersepsinya satu eksistensi realitas secara general (jenis),diferensiasi (nau') dan kausalitas.

Ketiga cara berfikir diatas haruslah saling bersinergi dan terintegrasi. Dengan kemampun berfikir pertama manusia akan mampu memenuhi kebutuhan hidup, baik secara fisik maupun biologis dan ini bertujuan agar manusia mendapat manfaat hidup. Disamping itu pula, kemampuan berfikir manusia bukan hanya sebatas pada tingkatan berfikir pertama. Manusia harus mampu mengintegrasikan antara tingkatan

${ }^{33}$ Abdurrahman bin Khaldûn, Muqaddimah Ibnu Khaldûn, h 156

Al Qalam: Jurnal Ilmiah Keagamaan dan Kemasyarakatan

Vol. 13, No. 1, Januari-Juni 2019 
Nashrullah Muhammad Atha: Reaktualisasi Konsep Integrasi Ilmu Ibnu Khaldun dalam Pendidikan Islam Modern

berfikir tamyîdzi dengan berfikir beragam ide dan moral sehingga keduanya saling bersinergi menjadikan manusia integratif dan inilah yang dimaksud oleh Ibnu Khaldûn dengan al `aqlu at tajrîbiy. Pada tingkatan berfikir teoritis manusia bukan hanya berfikir pada objek kongkret akan tetapi aqal nadzariy harus mampu berfikir pada dimensi abstrak sehingga akan memberikan konstribusi beragam ilmu pengetahuan.

Menurut Muhammad Kosim, Ibnu Khaldûn mengakui manusia sebagai makhluk dengan kepribadian integratif . Hal ini didasari dengan ada tiga dimensi unsur kepribadian manusia yang saling terintegrasi antara dimensi jasad, nafs dan ruh. Dengan dimensi jasad melalui perangkat indrawinya manusia memiliki kesamaan dengan binatang. Pada dimensi nafs/ jiwa Ibnu Khaldûn mengistilahkan jiwa dengan dimensi psikofisik. Pada dimensi ini ada dua arah hubungan manusia yang saling berintegrasi. Pertama, berhubungan dengan jasad/ indrawi yang mana jiwa lebih didoninasi oleh pengatahuan yang bersumber dari indera manusia dan hubungan ini berada pada arah bawah. Kedua hubungan ilmu pengetahuan dengan alam transenden atau dengan istilah roh. Maka dalam konteks perangkat indra tidak mungkin digunakan untuk mengakses ilmu pengetahuan. Walaupun nafs sifatnya gaib tapi efeknya visualnya bisa terdetisksi secara fisik. ${ }^{34}$

\section{Integrasi Adab}

Dalam Muqaddimahnya Ibnu Khladûn tidak secara eksplisit mendiskripsikan tema mengenai integrasi adab. Tema adab Ibnu Khladûn sisipkan pada pasal ketiga ketiga ia membahas materi "Akal Ekspremantal dan Cara Mengaktifkannya"35

Sebagai seorang sosiolog, Ibnu Khladûn menghubungkan studi adab dengan kajian sosial. Dalam prolognya Ibnu Khladûn memulia dengan

\footnotetext{
${ }^{34}$ Muhammad Kosim, Pemikiran Pendidikan Islam Ibnu Khaldûn, (Jakarta, PT Rineka Cipta, 2012), h, 47-49

${ }^{35}$ Abdurrahman bin Khaldûn, Muqaddimah Ibnu Khaldûn, h 160
}

Al Qalam: Jurnal Ilmiah Keagamaan dan Kemasyarakatan

Vol. 13, No. 1, Januari-Juni 2019 
Nashrullah Muhammad Atha: Reaktualisasi Konsep Integrasi Ilmu Ibnu Khaldun dalam Pendidikan Islam Modern

mengutip ungkapan para orang bijak, manusia tidak bisa dipisahkan sebagai makhluk sosial yang saling berintraksi. Manusia merupakan makhluk sosial yang eksistensinya sangat tergantung dengan interaksi bersama manusia yang lainnya dalam memenuhi segala kebutuhan hidup.

Terbentuknya sebuah komunitas sosial dalam masyarakat tentunya akan melahirkan beragama realitas interaktif baik secara positif ketika adanya kesamaan orientasi dan terkadang terjadi pula interaksi negatif yang berujung kepada petikaian dan konflik

Kompleksitas realitas sosial dimasyarakat tentunya memunculkan beragam nilai. Manusia dengan kemampuan akal eksprementalnya diharuskan mampu membedakan antara nilai-nilai positif maupun negatif. Dalam bahasa Ibnu Khladûn nilai-nilai yang hidup dalam realitas sosial dimasyarakat merupakan suatu yang riil yang semuanya dapat diketahui dan dipelajari melalui satu ekspremen begitu pula antara kebenaran dan kebohongan yang semuanya akan dibuktikan oleh waktu.

Dalam perspektif Ibnu Khladûn studi adab bukan hanya dipelajari secara teoritas dalam buku-buku teks. Studi adab harus teintegrasi dengan realitas sosial. Setiap generasi harus memiliki ekspreman realitas sosial sehingga ia mampu memahmi apa yang memang harus dikerjakan dan apa memang harus ditinggalkan dan kemampuan ini harus menjadi satu skil dalam setiap interaksinya.

Menurut Ibnu Khladûn, terkadang sebagian besar manusia mengalami akselerasi dalam hal ekspremen interaksi social. Hal ini dikarena mereka memiliki role model dari para orang tua atau generasi-generasi senior sebelumnya. Dari generasi-generasi inilah mereka belajar tentang adab secara aplikatif

Pembelajaran adab yang terkoneksi langsung dengan realitas sosial semacam inilah yang akan menjadikan setiap anak memiliki kepribadian yang terintegrasi. Studi adab bukan sebatas kajian-kajian teori. Studi adab harus menjadi kajian yang terintegrasi dengan realitas sosial. 
Nashrullah Muhammad Atha: Reaktualisasi Konsep Integrasi Ilmu Ibnu Khaldun dalam Pendidikan Islam Modern

Dalam perspketif Ibnu Khladûn, siap yang tidak memiliki ekspremen interaksi sosial dan role model atau ia tidak perduli dengan hal ini maka proses pembentukan adab akan menjadi satu melelahkan dan terkadang adab dan interaksi sosial tidak sesuai yang diinginkan. Kemudian Ibnu Khladûn mengitup satu ungkapan populer sekaligus memberikan komentar kritis mengenai adab:

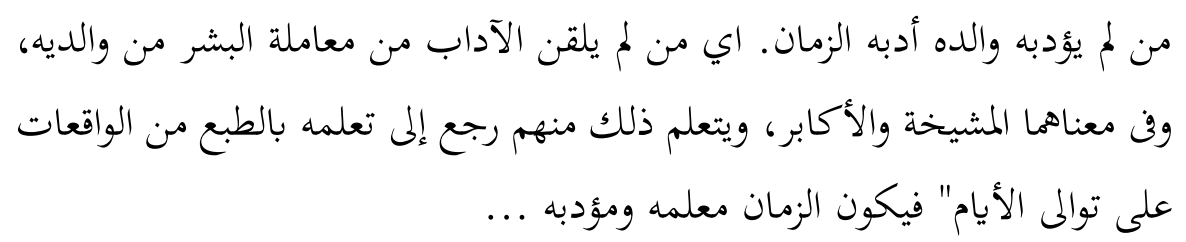

Dari ungkapan ini Ibnu Khladûn ingin menyampaikan bahwa para orang tua adalah orang yang paling bertanggung jawab dalam hal eksplorasi adab. Konsep pembelajaran adab yang dinginkan oleh Ibnu Khladûn adalah pembelajaran adab aplikatif. Dalam setiap interaksi social, para orang tua harus menjadi role model bagi anak-anaknya. Setiap orang tua yang abai dengan konsep pendidikan adab, maka sebagai konsekuensi logisnya anakanak mereka akan didik oleh realitas social sendirinya.

Konsep pendidikan adab yang ditawarkan oleh Ibnu Khladûn adalah pendidikan adab yang terintegrasi dengan realitas social. Realitas social menjadi objek dalam kajian adab. Dengan kemampuan orang tua dalam mengintegrasi adab terhadap realitas social menjadikan studi adab menjadi materi yang lebih realitas dan aplikatif.

Konsep adab integratif ini lahir dari kemampuan anak dalam memfungsikan akal ekspremen secara aktif. Konsep akal ekspremental bukan sebatas difugsikan dalam hal studi-studi kognitif saja. Akan tetap, akal ekspremental harus mampu difungsikan dalam kajian afektif. Dengan kemampuan akal ekspremental yang terintegrasi dengan realitas social diharapkan setiap anak memiliki proteksi terhadap nilai-nilai negative. 
Nashrullah Muhammad Atha: Reaktualisasi Konsep Integrasi Ilmu Ibnu Khaldun dalam Pendidikan Islam Modern

\section{Integrasi IImu}

Membaca tulisan Ibnu Khaldûn dalam kitabnya Muqqadimah maka secara eksplisit tidak ditemukan konsep integrasi ilmu secara utuh. Diskripsi implisit mengenai integrasi ilmu akan ditemukan pada kajian klasifikasi ilmu yang terbagi menjadi ilmu-ilmu naqliyah dan ilmu-ilmu aqliyah. Dalam konteks ini, Ibnu Khaldûn memberikan satu diskripsi bahwa antara kedua ilmu ini bukanlah suatu yang dikotomik. Dalam perspktif Ibnu Khaldûn, kedua ilmu merupakan objek ilmu pengetahuan yang menjadi kajian manusia. Selanjutanya Ibnu Khaldûn mendifinisakan kedua ilmu tersebut sebagai berikut:

a. lmu-ilmu rasional (aqliyah)

Manusia sebagai makhluk berfikir melalui perangkat kemanusiannya akan terbimbing mengetahui beragam tema, termasuk beberapa kajian argumentative dan beragam metode pembelajaran sehingga mampu mengklasifikasikan antara yang benar dan yang salah. ${ }^{36}$ Ilmu-ilmu rasional merupakan suatu yang natural bagi setiap manusia yang memiliki kemampuan berfikir dan ini tidak ada hubungannya dengan agama. Bahkan setiap agama memiliki kesamaan dalam melakukan eksplorasi kemampuan berfikirnya. Dan ini ada sejak adanya peradaban manusia. Menurut Ibnu Khaldûn, ada empat kategori ilmuilmu rasional, ilmu logika, ilmu aritmatika, ilmu music dan ilmu astronomi. ${ }^{37}$

b. Ilmu-ilmu tekstual (naqliyah)

Ilmu-ilmu naqliyah semuanya bersumber dari informasi wahyu sehingga akal manusia tidak memiliki otoritas kecuai pada konteks mengkoneksikan antara masalah-masalah fur $\hat{u}^{`}$ dengan masalah-masalah fundamental hal disebabkan karena beragam realitas yang terjadi tidak

\footnotetext{
${ }^{36}$ Abdurrahman bin Khaldûn, Muqaddimah Ibnu Khaldûn, h 171

${ }^{37}$ Abdurrahman bin Khaldûn, Muqaddimah Ibnu Khaldûn, h 247
}

Al Qalam: Jurnal Ilmiah Keagamaan dan Kemasyarakatan Vol. 13, No. 1, Januari-Juni 2019 
Nashrullah Muhammad Atha: Reaktualisasi Konsep Integrasi Ilmu Ibnu Khaldun dalam Pendidikan Islam Modern

akan mungkin terjawab melalui argementasi-argementasi teks. Menurut Ibnu Khaldûn, studi mengenai ilmu-ilmu naqliyah begitu banyak dan setiap mukallaf diwajibkan untuk mengenal hukum-hukum Allah. Di antara yang termasuk katagorisasi ilmu-ilmu tekstual adalah, ilmu tafsir, ilmu qiraat, ilmu hadits, ilmu fiqih, ilmu farâid, ushûl fiqih, ilmu kalam, tasawuf dan ilmu tafsir mimpi. ${ }^{38}$

Membaca realitas dinamika ilmu pengtahuan di Tunisia, Spanyol dan Mesir pada tahun ke $8 \mathrm{H}$ wacana konsep integrasi ilmu-ilmu tekstual dan rasional telah diperbincangkan oleh Ibnu Khaldûn dalam Muqaadimahnya dengan ungkapannya, Dengan runtuhnya Daulah Muwahhidîn di Marakesh maka Qadi Abu Al Qasim bin Zaitun melakukan rihlah ilmiyah dari Afrika ke bagian Timur pada pertengahan abad ke $7 \mathrm{H}$ dan kemudian bertemu dengan para murid Imam Ibnu Khatib yang telah menguasai ilmu-ilmu aqliyah dan ilmu-ilmu naqliyah. ${ }^{39}$

Masih menurut Ibnu Khaldûn, integrasi antara ilmu-ilmu aqliyah dan naqliyah merupakan satu realitas pendidikan yang terjadi pada sekitar tahun $8 \mathrm{H}$ pada komunitas ilmuan Maqribi, Tunisia, Spanyol dan Mesir. ${ }^{40}$

Dari hasil studi analisis Ibnu Khladûn mengenai klasifikasi ilmu pengetahuan maka terdapat 8 cabang ilmu pengetahuan terafiliasi kepada ilmu-ilmu naqliyah dan 12 ilmu yang terafiliasi kepada ilmu-ilmu aqliyah dengan skema sebagai berikut:

\begin{tabular}{|l|l|l|}
\hline No & $\begin{array}{l}\text { Ilmu-Ilmu Tekstual } \\
(\text { Naqiyah })\end{array}$ & Ilmu-Ilmu Rasional (Naqliyah) \\
\hline 1. & Ilmu Alquran & Matematika \\
\hline 2. & Ilmu Qiraat & Geometri \\
\hline 3. & Ilmu Hadîts & Astronomi \\
\hline 4. & Ilmu Fiqih & Ilmu Logika \\
\hline 5. & Ilmu Mawârits & Fisika \\
\hline
\end{tabular}

\footnotetext{
${ }^{38}$ Abdurrahman bin Khaldûn, Muqaddimah Ibnu Khaldûn, h 171-247

${ }^{39}$ Abdurrahman bin Khaldûn, Muqaddimah Ibnu Khaldûn...,

${ }^{40}$ Abdurrahman bin Khaldûn, Muqaddimah Ibnu Khaldûn...,
}

Al Qalam: Jurnal Ilmiah Keagamaan dan Kemasyarakatan

Vol. 13, No. 1, Januari-Juni 2019 
Nashrullah Muhammad Atha: Reaktualisasi Konsep Integrasi Ilmu Ibnu Khaldun dalam Pendidikan Islam Modern

\begin{tabular}{|l|l|l|}
\hline 6. & Ilmu Ushul Fiqih & Ilmu Kedokteran \\
\hline 7. & Ilmu Kalam & Ilmu Pertanian \\
\hline 8. & Tashawwuf & Ilmu Metafisik \\
\hline 9. & Ilmu Tafsir Mimpi & Ilmu Sihir dan Jimat \\
\hline 10. & & Ilmu Rahasia Huruf \\
\hline 11. & & Ilmu Kimia \\
\hline
\end{tabular}

Pandangan Ibnu Khaldûn mengenai materi-materi ilmu pengetahuan diatas, baik ilmu-ilmu aqliyah maupun naqliyah memberikan satu desain konsep integrasi ilmu pengetahuan yang harus memiliki keseimbangan. Menjadikan ilmu-ilmu naqliyah sebagai studi prioritas dalam kajian ilmu pengetahuan tidak harus meninggalkan kajian ilmu-ilmu rasional. Kedua ilmu harus saling berintegrasi dan bersinergi dalam membangun peradaban.

\section{E. Ibnu Khaldûn dan Reaktualisasi Konsep Integrasi Ilmu Dalam Pendidikan Islam}

Secara faktual, sebagian besar pendidikan Islam dewasa masih terkonsentarasi pada kajian-kajian naqliyah sebagai materi-materi primer. Sedangkan kajian-kajian rasionalistik dengan beragam disiplin ilmunya masih tersumsikan sebagai ilmu duniawi yang tidak memiliki ekfek ukhrawi. Adanya ikhtiyar sebagai sebagai pendidikan dalam melakukan integrasi ilmu pengetahuan masih bersifat parsial terkadang hanya sebatas labelisasi dengan penguatan ayatisasi.

Realitas faktual ini tentunya berbeda dengan realitas sejarah Islam yang memandang ilmu pengetahuan secara theosentrek ${ }^{41}$ sehingga terjadilah sinergi disemua disiplin ilmu. Dari sinergi ini terkonsepsi integrasi ilmu pengetahuan

41 Teori teosentrik bertolak belakang dengan teori antroposentrik yang berkembang di Barat yang memusatkan segala sesuatu pada manusia sehingga tuhan menjadi termarjinalkan. Ketika berbicara mengenai ilmu pengetahuan, maka temuantemuan ilmiah tidak harus mendapatkan rekomendasi dari agama, sekalipun temuan tersebut tidak sesuai dengan norma-norma kemanusian. 
Nashrullah Muhammad Atha: Reaktualisasi Konsep Integrasi Ilmu Ibnu Khaldun dalam Pendidikan Islam Modern

dalam Islam. Sinergi antara pesan-pesan wahyu dengan temuan ilmiah telah menjadi spirit dalam setiap kajian ilmu pengetahuan

Secara konstitusional sesuai dengan undang-undang Pendidikan dan Kebudayaan pasal 31 ayat 5 yang berbunyi "Pemerintah memajukan ilmu pengetahuan dan teknologi dengan menjunjung tinggi nilai-nilai agama dan persatuan bangsa untuk kemajuan peradaban serta kesejahteraaan umat manusia. Bunyi pasal 33 ayat 5 ini mengandung maksud bahwa dalam usahanya memajukan ilmu pengetahuan dan teknologi tidak boleh mengabaikan norma norma agama dan persatuan bangsa. tujuan dari memajukan ilmu pengetahuan dan teknologi adalah untuk kemajuan peradaban serta kesejahteraan umat manusia, khususnya warga negara Indonesia. ${ }^{42}$

Kedua pasal diatas memberikan satu pesan kuat mengenai konsep integrasi ilmu pengetahuan sehingga antara teknologi dan nilai-nilai agama bukan suatu yang dikotomik akan tetapi ilmu agama harus menjadi basis teknologi dalam mengembangkan peradaban bagi kesejahteran umat manusia. Walaupun pendekatan antara agama dan ilmu pengetahun berbeda, ${ }^{43}$ Akan tetapi keduanya haruslah saling berkorelasi dalam mencapai tujuan yang sama. ${ }^{44}$ Dalam bahasa Osman Bakar, epistemogi, metafisik, teologi dan psikologi memaikan peran yang

42 Pemanduan Pemasyarakatan Undang-Undang Dasar Negara Republik Indonesia Tahun 1945 dan Ketetapan Majelis Permusrawaratan Rakyat Republik Indonesia, (Jakarta: Sekretaris Jenderal MPR RI, 2014), h. 191

43 Ilmu pengetahuan berorientasi kepada penemuan makna pengalaman lahiriyah, sedangakan agama lebih difokuskan kepada asfek pengalaman ruhaniyah sehingga akan lahir kesadaran mendalam terhadap agama. Pada bagian-bagian tertentu ilmu pengetahun mungkin masih bisa mendiskripkan pengalaman-pengalaman keagaman, tetapi tetap tidak akan mungkin diukur dan dinyatakan dengan rumus-rumus pasti.Lihat Soedewo, Ilmu Pengetahuan dan Agama, (Jakarta, Darul Kutub Ilmiyha, 2007), h. 59.

44 Dalam pandangan Ahmad Mufli Saifuddin, agama dan sains keduanya memiliki perbedaan, namun tujuan keduanya memiliki kesamaan untuk menegaskan makna sebenarnya dari nilai kemanusian dan kehidupan manusia. Lihat Ahmad Mufti Saifuddin, Pengembangan Iptek Berwawasan Kemanusian dalam Masa Depan Kemanusian, (Yogyakarta, Jenndela, 2003), h.60

Al Qalam: Jurnal Ilmiah Keagamaan dan Kemasyarakatan

Vol. 13, No. 1, Januari-Juni 2019 
Nashrullah Muhammad Atha: Reaktualisasi Konsep Integrasi Ilmu Ibnu Khaldun dalam Pendidikan Islam Modern

sangat urgen dalam pengembangan intelektual dalam merumuskan varian relasi antara konseptual agama dan ilmu pengetahuan. ${ }^{45}$

Secara konseptual, kedua undang-undang ini telah didiksikan oleh Ibnu Khaldûn dalam Muqaddimahnya tujua abad yang lalu yang memandangnya ada korelasi ilmu pengetahuan dengan peradaban. Dalam perspektif Ibnu Khaldûn, ilmu pengetahuan dan pembelajaran merupakan suatu yang natural dalam peradaban umat manusia. ${ }^{46}$ Masih menurut Ibnu Khaldûn, peradaban merupakan satu kesatuan yang tidak bisa dipisahkan dengan ilmu pengetahuan. Jika peradaban telah runtuh, maka secara perlahan cahaya ilmu pengetahuan juga akan semakin melemah. ${ }^{47}$

Dari sini ditemukan suatu yang paradok antara realitas pendidikan Islam dengan realitas sejarah pendidikan Islam sendiri. Sementara itu, realitas faktual pendidikan Indonesia secara umum juga sangat paradok dengan amanah konstitusional. Tawaran konsep integrasi ilmu pengetahuan Ibnu Khaldûn menjadi kajian menarik untuk direaktualisasikan kembali dalam pendidikan kekinian.

a. Reaktualisasi Integrasi Intelektual

Pada usia 18 tahun Ibnu Khaldun telah menjadi intelektual integratif dengan keberhasilannya melakukan akselerasi penguasaan ilmu-ilmu naqliyah dan aqliyah. Usia 18 tahun dalam dunia pendidikan dewasa ini berarti telah menyelesai pendidikan tingkat atas untuk selanjutnya memasuki jenjang perguruan tinggi. Sementara itu Ibnu Khaldûn pada fase ini telah masuk pada fase belajar mandiri untuk selanjutnya mendapatkan amanah mengajar.

Terjadinya akselerasi integratif ini bisa dilihat dari teori pendidikan Ibnu Khaldûn dalam proses pencapaian ilmu pengetahuan. Dalam proses

45 Osma Bakar, Tawhid and Science; Islamic Perspective on Religion and Science, (Malaysia, sdn BHR, 2008), h.60

${ }^{46}$ Abdurrahman bin Khaldûn, Muqaddimah Ibnu Khaldûn, jilid 1, h. 165

${ }^{47}$ Abdurrahman bin Khaldûn, Muqaddimah Ibnu Khaldûn, jilid 1, h. 170

Al Qalam: Jurnal Ilmiah Keagamaan dan Kemasyarakatan

Vol. 13, No. 1, Januari-Juni 2019 
Nashrullah Muhammad Atha: Reaktualisasi Konsep Integrasi Ilmu Ibnu Khaldun dalam Pendidikan Islam Modern

pencarian ilmu pengetahuan, seorang pelajar harus difokuskan pada satu materi saja, tidak dibenarkan adanya dua ilmu yang menjadi objek studi oleh seorang pembelajar. ${ }^{48}$

Konteksualisasi teori pendidikan semacam bisa dilakukan dengan memfokuskan satu materi pembalajaran saja terlebih dahulu dengan target pencapaain terformulasi pemahaman siswa terhadap materi tersebut. Setelah materi ini selesai maka dilanjutkan dengan materi berikutnya dengan tetap memperhatikan kemampun siswa..

Secara materi, pembelajaran hanya difokuskan kepada masalahmasalah mendasar dengan menjadikan pokok bahasan sebagai objek diskrip materi dengan penjelasan yang masih bersifat global. Dalam pandangan Ibnu Khaldûn, kemampuan siswa dalam menerima materi ajar harus menjadi perhatian utama sehingga diharapakan daya fokus dan kesiapan siswa dalam memahami pembalajaran diharapkan sesuai dengan target akhir. ${ }^{49}$

Desain konsep pendidikan sitematis semacam ini tentunya akan memudahkan siswa dalam memahami materi ajar sehingga terjadi akselerasi pencapaian target pembelajaran. Tentunya yang diinginkan oleh Ibnu Khaldûn dari desain konsep pembelajaran semacam ini berlaku pada materimateri naqliyah dan aqliyah untuk selanjutnya kedua materi salling tersinergi secara integratif pada dari seorang pembelajar yang pada akhirnya lahir personalia integratif.

b. Reaktualisasi Integrasi Worldview

Personalian integratif masih bersifat integratif parsial karena masih berada dalam tatanan integrasi intelektual tanpa ada rekonstruski integrasi worldview. Integrasi materi ajar tanpa adanya internalisasi pesan-pesan wahyu pada akhirnya akan melahirkan intelektual ambigu. Dualisme

${ }^{48}$ Abdurrahman bin Khaldûn, Muqaddimah Ibnu Khaldûn, jilid 2, h. 347

Al Qalam: Jurnal Ilmiah Keagamaan dan Kemasyarakatan

Vol. 13, No. 1, Januari-Juni 2019 
Nashrullah Muhammad Atha: Reaktualisasi Konsep Integrasi Ilmu Ibnu Khaldun dalam Pendidikan Islam Modern

kepribadian lahir dari konsekuensi logis tidak bertrasnformasi kecerdasan intelektual pada pembentukan mental.

Terbentuknya integrasi worldview dimulai dengan merekonstruksi cara berfikir. Dan instrument yang paling berpengaruh terhadap pola pikir adalah ilmu pengetahuan. Berawal dari ilmu yang merekonstrusi cara berfikir yang selanjutnya melahirkan worldview. Dan dari worldview yang telah terformulasi secara massif pada akhirnya akan melahirkan peradaban. Oleh sebab itu, peradaban Islam bukan lahir dari bangunan fisik yang berlabelkan Islam, tapi adalah mereorientasikan framework umat Islam. ${ }^{50}$

Ibnu Khaldûn dengan teori 3 klasifikasi yang dimulai dari al ‘aqul tamyîdziy yang lebih didominasi oleh persepsi (tashawwurât) terhadap objek empiris pragmatis. Dari al `aqlul tamyîdzi naik menjadi al `aqlul tajribiy dengan kemampuan eksplorasi ide-ide yang terintegrasi dengan adab yang lahirnya dari beragama apersepsi (tashdiqât). Selanjutnya dari koneksitas kedua akal tersebut, kemampuan berfikir manusia naik menjadi al ‘aqul nazhariy dengan kemampuan berfikir transenden yang lahir dari ilmu atau yang masih bersifat praduga. Al aqlu nazhariy merupakan sinergi dari beragam persepsi dan apersepsi.

Membaca karakteristik al `aqlul nazhariy dengan kemampuan berfikir yang melahirkan ilmu pengetahuan tentunya harus bersumber dari wahyu. Sebagaimana pendefinisian Syekh Ibnu Tamiyah tentang ilmu pengetahuan yang harus didasari pada dalîl. Dan dalîl yang dimaksud terbagi menjadi dua, dalîl yang lahir dari metode yang benar (al naqlul mushaddaq) atau dalîl dalam bentuk penelitian ilmiah (al bahtsul muhaqqah). ${ }^{51}$

Dalam Islam, setiap ilmuan dengan kemampuan al `aqlul nazhariy harus terbentuk dari worldview islami yang bersifat integratif. Worldview

50 Hamid Fahmy Zarkasyi, Epistemologi dalam Pemikiran Islam, Majalah Pemikiran dan Peradaban Islam Islamia, Thn II No 5 April 2005

51 Ibnu Taimiyah, Majmu` Al Fatâwi Syekh Al Islâm Ahmad ibnu Taimiyyah, (Beirut, Muassalah Risâlah, 1997), jilid, 6, h. 388

Al Qalam: Jurnal Ilmiah Keagamaan dan Kemasyarakatan

Vol. 13, No. 1, Januari-Juni 2019 
Nashrullah Muhammad Atha: Reaktualisasi Konsep Integrasi Ilmu Ibnu Khaldun dalam Pendidikan Islam Modern

integratif menjadi sangat urgen dalam kontek pendidikan kekinian. Meminjam ungkapan Adian Husaini, kalangan terpelajar dengan kerangka epistemologis Islami harus mampu mengintegrasikan tiga hal, ilmu yang merupakan jalur indrawi, akal dan wahyu Allah. Konsep-konsep kehidupan yang dihasilkannya pun harus bersifat integral dan tidak parsial yang hanya mengandalkan kekuatan akal dan indra semata. Seorang ilmuan geologi misalnya, tidak hanya bicara tentang fenomena gempa bumi sebagai gejala alam semesta, tetapi juga mengajak rakyat untuk mendekatkan diri kepada Allah agar tidak tertimpa azab Allah. ${ }^{52}$

c. Reaktualisasi Integrasi Adab

Pilihan kata adab yang digunakan Ibnu Khaldûn memberikan satu pesan kuat bahwa terjadi integrasi antara materi-materi naqliyah dan aqliyah dalam tataran intelektual harus mampu berhasil terintegrasi dengan nilai-nilai adab. Realitas pendidikan kekinian masih melihat adab bukan suatu kecerdasan yang harus mendapatkan nilai. Konsep berfikir dikotomik semacam menjadi satu problematika dalam dinimaka pendidikan kekinian.

Sebagai seorang sosiolog, Ibnu Khaldûn melihat adab bukan sebatas pembelajaran diruang-ruang kelas. Studi adab merupakan studi aplikatif terhadap realitas masyarakat yang sedang berkembang. Disinilah perang orang tua menjadi hal yang sangat urgen dalam memformulasikan materimateri adab aplikatif sejak dini pada setiap anak. Ibnu Khaldûn telah menjadikan materi adab sebagai materi internalisasi dini nilai Islam terhadap setiap anak agar terproteksi dari nilai-nilai negatif.

Dengan meminjam istilah Nuqaib Al Attas sebagai mana yang dituliskan oleh Adian Husaini, problem utama umat Islam berakar pada masalah "loss of $a d a b$ ". Hilangnya adab itulah akar masalah yang dihadapi

52 Adian Husaini, Pendidikan Islam Mewujudkan Generasi Gemilang Menuju Negara Adidaya 2045, (Depok, At-Taqwa, 2018), h. 254

Al Qalam: Jurnal Ilmiah Keagamaan dan Kemasyarakatan

Vol. 13, No. 1, Januari-Juni 2019 
Nashrullah Muhammad Atha: Reaktualisasi Konsep Integrasi Ilmu Ibnu Khaldun dalam Pendidikan Islam Modern

umat Islam saat ini. ${ }^{53}$ Islam menjadikan adab di atas ilmu pengetahuan sebagaimana ungkan populer, al `adabu fauqal ilmi. Bagi seorang ilmuan, adab harus menjadi satu prioritas utama dalam pencapaian ilmu pengetahuan. Dari sinilah diharuskan adanya studi adab aplikatif bagi para ilmuan.

Studi adab menjadi materi urgen yang harus didapatkan setiap ilmuwan, baik moralitas kepada Allah maupun kepada hamba-Nya. Dalam Islam, antara ilmu dan akhlak merupakan satu keniscayaan yang tidak bisa dipisahkan. ${ }^{54}$ Terjadinya akselarasi ilmu pengetahuan haruslah disinergikan dengan kepekaan terhadap moralitas. Islam tidak membenarkan lahirnya ketimpangan antara ilmu dan moral. Setiap hasil penelitian dan pencapaian penemuan harus berorientasi kepada moralitas bukan materi semata. Dengan studi moralitas, kecerdasan angka-angka bukan menjadi standar keberhasilan dan kesuksesan.

Sejarah peradaban Islam telah mengajarkan kepada kita semua, bahwa para ilmuan klasik telah menjadikan moralitas sebagai standard ilmu pengetahuan, sehingga setiap pencapaian yang dihasilakan melalului proses ilmu pengetahuan akan mengantarkan kepada kematangan moralitas. Dalam

${ }^{53}$ Adian Husaini, Mewujudkan Indonesia Adil dan Beradab, (Surabaya, Bina Qalam Indonesia, 2015), h. 100

${ }^{54}$ Konsep integrasi adab dan ilmu pengetahuan tentunya berbeda dengan konsep keilmuan di Barat yang menjadikan adab bukan sebagai materi pendidikan dan kualitas keilmuan. Adian Husaini dalam bukunya Hegemoni Kristan Barat dalam Studi Islam di Perguruan Tinggi mengutipkan tulisan Paul Johnson dalam "Intellectuals" memamparkan kebajatan moral sejumlah ilmuan besar yang menjadi rujukan keilmuan di Barat dan dunia internasional, sebut saja Ruosseau yang tertulis sebagai manusia gila yang menarik (an interesting madman). Pada tahun 1728, saat berumur 15 tahun dia bertukar agama menjadi Katolik agar dapat menjadi peliharaan Mademe Francoise. Ernest Hemingway, seorang ilmuan jenius tidak memiliki agama yang jelas. Istrinya menyebutkan bahwa Hemingway hanya pernah sembahyang dua kali, saat perkawinan dan dan pembaptisan anakanya. Untuk menyenangka istri keduanya, Pauline dia berganti agama menjadi Katolik Roma. Hemingway bukan saja tidak percaya kepada Tuhan, tapi menganggap "organized religion" sebagai ancaman terhadap kebahagian. Adian Husaini, Hegemoni Kristan Barat dalam Studi Islam di Perguruan Tinggi,(Jakarta, Gema Insani, 2006), h. 56-57

Al Qalam: Jurnal Ilmiah Keagamaan dan Kemasyarakatan

Vol. 13, No. 1, Januari-Juni 2019 
Nashrullah Muhammad Atha: Reaktualisasi Konsep Integrasi Ilmu Ibnu Khaldun dalam Pendidikan Islam Modern

Islam, semakin berkualitas ilmu seseorang maka semakin tinggi pula kualitas moralitas, keduanya menjadi satu kesatuan yang tidak bisa dipisahkan dan klimak dari kematangan moralitas terpolarsasinya proteksi maksiat. ${ }^{55}$

d. Reaktualisasi Institusi

Cerita Ibnu Khaldûn dalam Muqaadimahnya mengenai Qadi Abu Al Qasim yang bertemu dengan murid-murid Imam Ibnu Khatib untuk kemudian ikut belajar bersama sehingga Qadi Abu Qasim berhasil mensinergikan antara ilmu-ilmu naqliyah dan aqliyah. Institusi integratif ini juga masih menjadi tren pada kurun waktu abad ke $8 \mathrm{H}$ sebagaimana bisa dilihat di Maqrib, Tunisia, Spayol dan Mesir.

Visualisasi Ibnu Khaldûn merupakan bentuk dari terkurikulumkan materi-materi naqliyah dan aqliyah secara integratif dalam sebuah institusi pendidikan ketika itu. Integrasi ilmu dan agama tidak dapat dilakukan secara formalitas dengan cara memberikan justifikasi ayat al-Qur'an pada setiap penemuan dan keilmuan, memberikan label agama atau Islam pada istilahistilah keilmuan dan sejenisnya, tetapi perlu ada perubahan paradigma pada basis keilmuan Barat, agar sesuai dengan basis dan khazanah keilmuan Islam yang berkaitan dengan realitas metafisik, religius dan teks suci. Hal ini penting, sebab sebuah ilmu akan tetap bernafaskan sekuler, jika tidak didasarkan pada basis ontologism atau pandangan dunia (world view) atau

55 Suatu hari Imam Syafi'I sedang berjalan disalah satu pojok kota. Angin berhembus lumanyan kencang. Lelaki yang telah hafidz Qur`an pada usia beliu itu terlihat tenang. Beberapa wanita berjalan dihadapannya. Angin kembali berhembus. Tiba-tiba ketika Imam Syafi'I menatap kedepan, dilihatnya pakaian wanita itu tersingkap sehingga terlihat betisnya. Wanita itu berusaha membenahi kembali pakaiannya. Rona wajahnya diliputi rasa malu. Imam Syafi'I tertegun, dari bibirnya terlafadz ratusan istigfar karena takut tehadap waksiat yang baru saja ia lakukan. Dengan tergesa-gesa Imam Syafi i mengambil air wudhu kemudian shalat didalam masjid dengan selalu melafadz istiqfar. Sikap Imam Syafi'I ini menimbulkan rasa anek terhadap salah seorang jamaah yang kemudian menanyakan apa hal yang terjadi. Imam Syafi'I pun menceritakan peristiwa yang baru saja ia alami. Inilah sebuah realitas jiwa yang telah terbersihkan dengan materimateri tazkiyatun nafsi sehingga maksiat menjadi satu yang sangat ditakuti. Lihat, Dwi Budyanto, Prohetic Learnig, (Yogyakarta, Pro-U Media, 2009), h. 117-118

Al Qalam: Jurnal Ilmiah Keagamaan dan Kemasyarakatan

Vol. 13, No. 1, Januari-Juni 2019 
Nashrullah Muhammad Atha: Reaktualisasi Konsep Integrasi Ilmu Ibnu Khaldun dalam Pendidikan Islam Modern

tauhid menurut istilah Nuqaib al-Attas. Begitu juga, sebuah epistemologi akan tetap bersifat 'eksploitatif' dan 'merusak' jika tidak didasarkan pada ontologi yang Islami. Meski demikian, bangunan ilmu yang telah terintegrasi tidak banyak berarti jika dipegang oleh orang yang tidak bermoral dan tidak bertanggung jawab, maka perlu dibenahi pada aspek aksiologinya. ${ }^{56}$ Dengan demikian, pengembangan pendidikan Islam bertolak dari konstruk pemikiran atau epistemologi bahwa yang vertikal (ajaran dan nilai-nilai Ilahi) merupakan sumber konsultasi, sentral dan didudukkan sebagai ayat, furqân, hudan, dan rahmah. Sedangkan yang horizontal (pendapat, konsep, teori, temuan-temuan dan sebagainya) berada dalam posisi sejajar yang saling sharing ideas, selanjutnya dikonsultasaikan pada ajaran dan nilai-nilai Ilahi terutama yang menyangkut dimensi aksiologis. ${ }^{57}$

Pandangan seperti itu akan berimplikasi pada model kurikulum dan proses pembelajaran yang dikembangkan di perguruan tinggi keagamaan Islam, yang tidak hanya menekankan pada penguasaan ilmu agama Islam, tetapi juga menekankan pada bagaimana ilmu pengetahuan dan teknologi serta seni menerangkan berbagai problem yang dihadapi kaum muslimin dalam kehidupan kesehariannya.

Perguruan tinggi keagamaan Islam sebagai perguruan tinggi yang menyelenggarakan program pendidikan akademik, vokasional dan atau professional, mengemban misi untuk menyiapkan calon-calon lulusan yang mampu mengintegrasikan "kepribadian ulama yang intelek dan atau intelekprofesional yang ulama" sesuai dengan bidang studi atau keahlian yang ditekuni, yang diwujudkan dalam kehidupan bermasyarakat, berbangsa dan

${ }^{56}$ A. Khudlori Sholeh, "Pokok Pikiran tentang Paradigma Integrasi Ilmu dan Agama" dalam M. Lutfi Musthofa, Helmi Syaifuddin(ed), Intelektualisme Islam Melacak Akar-akar Integrasi Ilmu dan Agama, (Malang: Lembaga Kajian al-Qur'an dan Sains UIN Malang, 2006), h. 261-262.

${ }^{57}$ Muhaimin. Wacana Pengembangan (Yogyakarta: Pustaka Pelajar, 2003), h. 
Nashrullah Muhammad Atha: Reaktualisasi Konsep Integrasi Ilmu Ibnu Khaldun dalam Pendidikan Islam Modern

bernegara di tengah-tengah kehidupan yang semakin global. ${ }^{58}$ Konsekuensinya diperlukan tenaga-tenaga yang berwawasan imtaq dan iptek, dan buku-buku teks yang bernuansa agamis pada setiap bidang studi yang diprogramkan.

Lingkungan religius di lembaga pendidikan, pada gilirannya akan berdampak pada pengembangan pandangan hidup dan ketrampilan hidup yang berprespektif Islami, akan sulit tercipta jika tidak didukung oleh seperangkat sarana dan prasarana serta tenaga kependidikan yang mampu mengembangkan nilai-nilai Islam. Karena itulah, perguruan tinggi keagamaan Islam perlu mengembangkan program yang memiliki tujuan ganda, yaitu pendalaman dan pengayaan wawasan akan ilmu-ilmu keislaman, serta pembinaan ruh keislaman dan atau internalisasi nilai-nilai Islam.

Dalam rangka menjadikan perguruan tinggi keagamaan Islam sebagai pusat pengembangan mahasiswa yang memiliki keunggulan akademik dan moral, perlu reformulasi ilmu pengetahuan integratif. Untuk mewujudkan ini, perguruan tinggi keagamaan Islam telah berusaha mengembangkan konsep keilmuan dan moralitas. Pengembangan ini menjadi tidak berarti banyak jika tidak diimbangi dengan pengembangan hubungan organik antara ilmu, iman dan amal shaleh. Mengingat etos keilmuan tidak dapat dibangun hanya melalui pembelajaran secara formal di dalam kelas, maka meniscayakan adanya wadah akademik (academic sphere) yang memberikan ruang gerak bagi perkembangan akal dan moral, sehingga mendukung perkembangan intelektual dan keberagamaan. ${ }^{59}$

${ }^{58}$ Ibid., h. 271.

${ }^{59}$ Di Perguruan Tinggi masih terdapat perbedaan dalam menyusun visualisasi integrasi antara agama dan ilmu. Jika di UIN Sunan Kalijaga integrasi-interkoneksi ilmuilmu agama dan umum menggunakan model dengan nama sarang laba-laba, UIN Sunan Ampel menggunakan lambang model Twin Towernya, UNY dengan model segitiga, atau nampaknya lebih tepat dengan bangunan trapesium, berbeda lagi dengan dengan UIN Maulana Malik Ibrahim dengan nama pohon ilmu, atau mungkin juga akan banyak model sesuai back-ground masing- masing Perguruan Tinggi. Tetapi semuanya mempunyai

Al Qalam: Jurnal Ilmiah Keagamaan dan Kemasyarakatan

Vol. 13, No. 1, Januari-Juni 2019 
Nashrullah Muhammad Atha: Reaktualisasi Konsep Integrasi Ilmu Ibnu Khaldun dalam Pendidikan Islam Modern

\section{F. Kesimpulan}

Keterputusan koneksitas terhadap sejarah pendidikan Islam klasik yang telah berhasil memberikan fakta-fakta historis lahirnya para ulama ilmuan dan ilmuan ulama yang telah berhasil melakukan ekspolorasi pesan-pesan wahyu dalam mendesain pendidikan integratif telah menyebabkan pendidikan modern dewasa dihadapkan dengan problemtaika dikotomik yang meniscayakan adanya solusi integratif.

Konsep-konsep pendidikan Islam klasik bukan sebatas teorits historis sebagai jawaban terhadap realitas klasik dizamannya yang telah mengalama stagnasi implementasi. Kontekstualisasi pesan-pesan wahyu telah melahirkan kekhasan konseptualisasi pendidikan Islam lintas sejarah dan peradaban. Teoriteori pendidikan Islam klasik merupukan hasil dengan kreatifitas berfikir para pakar pendidikan dalam merekonstruksi pesan-pesan wahyu menjadi lebih adaptif dan realitis.

Toeri integrasi materi ilmu-ilmu naqliyah dan aqliyah yang telah didiskripsikan Ibnu Khaldûn dalam Muqaddimahnya telah menempatkan Ibnu Khaldûn sebagai seorang sosiolog Arab integratif. Teori integrasi yang ditawarkan Ibnu Khaldûn tentunya bukan sebatas teori historis. Dari hasil analisis peneliti, Ibnu Khaldûn dengan masterpiece-nya dengan focus kajian mengenai pendidikan telah berhasil memformulasikan konsep ilmu pengetahuan dengan pendekatan saintifik rasional empiris melalui teori studi ilmu-ilmu aqliyah untuk selanjutkannya terintegrasikan melalui pendekatan tekstualis transenden yang didasari dari al naqlul mushaddaq melalui teori studi pesan-pesan naqliyah.

Kreatifitas intelektual peneliti diharuskan mampu melakukan eksplorasi teori dengan melalui tipice appoarch yang kemudian disinergikan melalui metodologi diskriptif analitik sehingga pada akhirnya teori-teori klasik ulama

\footnotetext{
kesamaan visi dan misi bahwa pendidikan Islam tidak memisahkan, bahkan tidak mengenal pembidangan ilmu-ilmu agama dan ilmu-ilmu umum. Karena al-Quran dan hadits, baik dari segi redaksi maupun maknanya membahas semua yang ada di dalam realitas kehidupan mulai tentang penciptaan alam semesta, manusia, binatang, hingga sampai pada persoalan setelah kematian manusia dan kiamat.
}

Al Qalam: Jurnal Ilmiah Keagamaan dan Kemasyarakatan

Vol. 13, No. 1, Januari-Juni 2019 
Nashrullah Muhammad Atha: Reaktualisasi Konsep Integrasi Ilmu Ibnu Khaldun dalam Pendidikan Islam Modern

Islam menjadi sebuah alternatif solutif terhadap problematika pendidikan Islam dikotomik. 
Nashrullah Muhammad Atha: Reaktualisasi Konsep Integrasi Ilmu Ibnu Khaldun dalam Pendidikan Islam Modern

\section{Daftar Pustaka}

Abdurrahmân bin Khaldûn, Muqaddimah Ibnu Khaldûn, Damsyik, Dârul Balkhi, 2004

, At Ta`rîf bi Ibni Khaldûn wa Rihlatihi Garban wa Syarqan,

Lebanon, Dârul Kitâb, 1979

Adian Husaini, Pendidikan Islam Mewujudkan Generasi Gemilang Menuju Negara Adidaya 2045, Depok, At-Taqwa, 2018

, Mewujudkan Indonesia Adil dan Beradab, Surabaya, Bina Qalam Indonesia, 2015Adian Husaini, Hegemoni Kristan Barat dalam Studi Islam di Perguruan Tinggi,Jakarta, Gema Insani, 2006), h. 56-57

Ahmad Mufti Saifuddin, Pengembangan Iptek Berwawasan Kemanusian dalam Masa Depan Kemanusian, Yogyakarta, Jenndela, 2003

Al-Majlis al-'Ala li Syu'ûn al-Islâmiyyah, "Mausû̀ah al-Hadhârah alIslamiyyah",Mesir, 1426 H/2005

Abuddin Nata, et al.eds. Integrasi Ilmu Agama dan Umum Jakarta:Grafndo Persada, 2005

Alī 'Abd al-Wāhid Wāfì, 'Abd al-Rahmān ibn Khald̄̄n: Hayātuhu wa Ātsāruhu wa Mazhāhir 'Abqariyyatihi Mesir: Maktabah Misr, t.t

Abdul Amir Syamsuddîn, Mausû‘ah At Tarbawiyah wa Ta'lîm Al Islamiyyah Al Fikru At Tarbawiyyu `inda Ibnu Khaldûn wabnu Al Arzâq,

Burhan Bungi, Analisis Data Penelitan Kualitatif, Pemahaman Filsafat dan Metodologis ke Arah Penguasaan Model Aplikasi, Jakarta, Raja Grafindo Persada, 2003

Dwi Budyanto, Prohetic Learnig, Yogyakarta, Pro-U Media, 2009

Fahmi Amhar, TSQ Stories “Kisah-Kisah Penelitian dan Pengembangan Sains dan Teknologi di Masa Peradaban Islam, Jakarta, Al-Azhar Press, 2010

Hamid Fahmy Zarkasyi, Epistemologi dalam Pemikiran Islam, Majalah Pemikiran dan Peradaban Islam Islamia, Thn II No 5 April 2005 
Nashrullah Muhammad Atha: Reaktualisasi Konsep Integrasi Ilmu Ibnu Khaldun dalam Pendidikan Islam Modern

Helmi Syaifuddin (ed), Intelektualisme Islam Melacak Akar-akar Integrasi Ilmu dan Agama, Malang: Lembaga Kajian al-Qur'an dan Sains UIN Malang, 2006

Ibnu Taimiyah, Majmu`Al Fatâwi Syekh Al Islâm Ahmad ibnu Taimiyyah, Beirut, Muassalah Risâlah, 1997

Ismail Sirâjuddîn, Ibnu Khaldûn Injâzun Fikriyyun Mutajaddidun, (Mesir, Maktabah Iskandariyah, 2008

I Made Wirantha, Metode Penelitian Sosial Ekonomi, Yogyakarta, Andi, 2006

Mardalis, Metode Penelitian: Sesuatu Pendekatan Proposal, Jakarta, Bumi Aksara, 1995

Muhaimin. Wacana Pengembangan Yogyakarta: Pustaka Pelajar, 2003

Muhammad Kosim, Pemikiran Pendidikan Islam Ibnu Khaldûn, Jakarta, PT Rineka Cipta, 2012

Muhammad Athiyyah al-Abrâs, ‘Azhamatul Islam, Mesir, Maktabah al-Usrah, .2000

Muhamam Pribadi, Tahapan Pemikiran Masyarakat Dalam Pandangan Ibnu Khaldun Sosiologi Reflektif, Volume 11. No 2 April 2017

Muhammad Fārūq al-Nabhān, al-Fikr al-Khaldūn̄̄ min Khilāl al-Muqaddimah Beirut-Lebanon: Mu'assasah al-Risālah,1417 H/1998 M

Muhammad Natsir: Dakwah dan Pemikirannya, Jakarta, Gema Insani, 1999

Nizar, Sejarah Pendidikan Islam: Menelusuri Jejak Sejarah Pendidikan Era Rasulullah sampai Indonesia, Jakarta, Kencana Prenada Media, 2009

Mujamil Qamar, Dimensi Manajemen Pendidikan Islam, Jakarta, Emir, 2015

Muslih Usa, et.al, Pengantar, dalam Pendidikan Islam di Indonesia: Antara Cita dan Fakta Yogyakarta: PT Tiara Wacana Ilmu, 1997

Nâshiruddîn Abi Khair Abdullah bin Umar,Tharhu Tatsrîb, Mesir, Dâr Ihyâ Turâts Al Arabiyyi, t.t

Noeng Muhajir, Metode Penelitian Kualitatif, Bandung, PT Remaja Rosdakarya, 1990 
Nashrullah Muhammad Atha: Reaktualisasi Konsep Integrasi Ilmu Ibnu Khaldun dalam Pendidikan Islam Modern

Sugiyono, Metode Penelitian Kuantitatif dan R \& D, Bandung, Alfabete, 2012

Soedewo, Ilmu Pengetahuan dan Agama, Jakarta, Darul Kutub Ilmiyha, 2007

Yusuf Qaradhawi, Al-Hayâtu Ar-Rabbâniyyah wal Ilmi Mesir, Maktabah Wahbah, 2002 